\title{
Threat to the Welfare of the Child by Unprofessional Attempts to Create a New Family Code
}

\begin{abstract}
The aim of the article is to evaluate the draft of a new Family Code developed by the Social Codification Commission for Family and Guardianship Law attached to the Children's Rights Ombudsman with regard to the advisability and legitimacy of the changes proposed in it, as well as to analyse its selected detailed solutions in the context of their impact on the protection of the child's welfare. The aforementioned detailed issues concern, among others, the issues of parental custody and material and legal grounds for divorce. The proposed changes, namely the replacement of the institution of parental custody with "parental responsibility" and the introduction of a new divorce premise are perceived by the authors of the article as clearly negative.

The authors of the article are also critical of the procedure of preparation of the discussed draft. In their opinion, the applicable Family and Guardianship Code is not an anachronistic legal act and can and should continue to play the role of a basic regulator of legal and family relations in our country. The proposal to replace it with a new code is not sufficiently justified, either legally or socially, and its adoption may prove to be dangerous for the stability of the legal and family regulations, shaped by the latest amendments to family law and contrary to the principle of protection of the best interests of the child.
\end{abstract}

Keywords: welfare of the child, threat to the welfare of the child, family code

1 Prof. Wanda Stojanowska - Faculty of Law and Administration, Cardinal Stefan Wyszyński University in Warsaw; e-mail: w.stojanowska@uksw.edu.pl; ORCID: 0000-0002-1915-3555.

2 Rev. Mirosław Kosek, PhD - Faculty of Law and Administration, Cardinal Stefan Wyszyński University in Warsaw; e-mail: m.kosek@uksw.edu.pl; ORCID: 0000-0002-5519-0329. 


\section{Introductory Remarks}

The Polish family law has been the object of intense legislative activity for some time. This activity takes various forms - of draft amendments to the individual provisions of the Family and Guardianship Code, of changes regarding the entire institutions of the Code (e.g. parental authority or divorce), and even of drafts of a completely new Family Code. On the one hand, this activity is understandable and acceptable - even necessary in some cases - if it is a thoughtful and balanced answer of the legislator to the issues of the practice or the dynamics of social changes, which also covers broadly understood family reality. On the other hand, however, this practice may cause justified concern, especially in the context of the more and more common practice of the "express" preparation and making of proposed changes, and the excessive influence of the current politics on the course and nature of these changes. This tendency is more common and it does not concern only the provisions of the family law, but it is they which, due to the nature and sensitivity of the subject of the regulations, as well as due to the social meaning of these norms, should be specially protected primarily because they concern the basic fabric which is the family and children raised in it.

The purpose of this paper is to assess the draft of a new Family Code prepared by the Social Codification Commission for the Family and Guardianship Law attached to the Ombudsman for Children ${ }^{3}$ as regards the advisability and legitimacy of the changes proposed in it, and to analyse its selected detailed solutions in the context of their impact on the protection of the child's welfare. The analysis concerns only the part of the draft which includes substantive provisions, whereas it omits the legal-procedural part and the executive one. It already befits one to mention here that joining such different regulations in one legal act raises serious doubts.

3 The Commission was appointed by the Ombudsman for Children in 2012 and after several years of its activity, it prepared an extensive collection of provisions, calling it "The Draft Family Code". This draft was published on the website of the Ombudsman for Children (www.brpd.gov.pl) with information that it was sent to various national institutions, i.a. to the President of the Republic of Poland, the Sejm and the Senate of the Republic of Poland, in order to subject it to a legislative process. 


\section{The General Description of the Draft}

\section{The Advisability and Legitimacy of the Changes}

An analysis of the drafts of new legal regulations is usually focused on the content of individual provisions and the scope of the proposed changes in comparison with the applicable state of law. However, in the case of such a fundamental change as the draft of a new (Family) Code, it befits one to start the subjective reflections from the issue of the advisability of the change. ${ }^{4}$ The analysis of the statement of reasons for the draft, and particularly its diagnosis of the current social and family situation in Poland, and the evaluation of the applicable Family and Guardianship Code, which constitute a justification for the designed changes, provides an insight into this matter.

The reason for undertaking work on the draft of the new Family Code - as the statement of reasons appended to the draft reads - was the necessity of adjusting the provisions of the family law "to the new philosophy of understanding family-legal issues, thinking about the child and the family, their subjectivity, and about protecting these goods, as well as the introduction of modern legal solutions of those issues, which match the reality," ${ }^{15}$ as well as "the introduction of changes concerning the new, European definition of family relations." ${ }^{16}$ In the opinion of the authors of the draft, "the applicable Family and Guardianship Code, as regards substantive family law, fulfilled its tasks up to the time of the system transformation in Poland in the 1990s."7 In particular, "the current understanding of human rights, including the rights of the child, the rights of the family - in comparison with the currents of thought of the 1960s - as well as the reality which the modern family came to live in, are completely different." ${ }^{\prime 8}$

The current social context of the functioning of the norms of the family law, which was presented in the statement of reasons for the draft, as well as the evaluation of the applicable Family and Guardianship Code raise serious doubts. The above-quoted claims of the authors of the statement of reasons are contradicted

4 For further information, see: W. Stojanowska, M. Kosek, O rzekomej potrzebie nowego Kodeksu rodzinnego, [in:] Tempora mutantur cum legibus. Księga Jubileuszowa z okazji 20-lecia Wydziatu Prawa i Administracji UKSW w Warszawie, Warszawa 2019, p. $153 \mathrm{ff}$.

5 See: Statement of reasons for the draft of the new Family Code (Uzasadnienie projektu nowego Kodeksu rodzinnego), http://brpd.gov.pl/sites/default/files/projekt_kodeksu_rodzinnego_z_autopoprawka_z_uzasadnieniem.pdf., p. 95.

6 Statement of reasons for the draft, p. 101.

7 Ibidem, p. 96.

$8 \quad$ Ibidem, p. 97. 
by the fact of numerous and - what is more important - pivotal amendments to the Family and Guardianship Code since it was adopted, also, and even first of all, after the system transformation mentioned in the statement of reasons for the draft. They fundamentally changed solutions adopted in the original version of the Code which were applicable at the time of its coming in force. It befits the amendment of 17 June $2004^{9}$ regarding marital property systems to be mentioned here. It adjusted this problem to social and economic changes which occurred in Poland in the 1990s. The extensive amendment of 6 November $2008^{10}$ should also be mentioned here. Its purpose was "adjusting the rules of the Family and Guardianship Code, concerning relations between parents and children to the changed social and legal context of applying code provisions," including international agreements ratified by Poland, as well as postulates formulated in the doctrine, the judicature, and "in speeches by the Commissioner for Human Rights and the Ombudsman for Children." ${ }^{11}$ The aforementioned amendment of 6 November 2008 introduced provisions concerning the determination and denial of maternity, contact with the child into the Family and Guardianship Code. Fundamental changes to the provisions concerning child acknowledgement (currently the acknowledgement of paternity), and provisions shaping the institution of parental authority after the divorce. In this context, claiming that the applicable Family and Guardianship Code "fulfilled its tasks up to the time of the system transformation" or it was purportedly still inspired by "the currents of thought of the $1960 \mathrm{~s}$ " is, to put it very mildly, a misunderstanding. In this context, it is also worth emphasising that the aforementioned amendment of 6 November 2008 was prepared by the Team of Family Law of the Codification Commission for Civil Law which agglomerates outstanding family law experts, including the ones who practise law. The aforementioned Team's professionalism is indicated not only by its members' qualifications, but also by the procedure applied in the course of preparing the draft. ${ }^{12}$ It is hard to make an allegation against that assembly of supporting rules which are not modern

9 Journal of Laws of 2004 No. 162, item 1691.

10 Journal of Laws of 2008 No. 220, item 1431. For further information on this amendment, see: W. Stojanowska, M. Kosek, Nowelizacja prawa rodzinnego na podstawie ustaw z 6 listopada 2008 r. i 10 czerwca 2010 r. Analiza - Wykładnia - Komentarz, W. Stojanowska (ed.), Warszawa 2011.

11 See: Statement of reasons for the Government Bill on Amending the Act - Family and Guardianship Code, and Certain Other Acts, form No. 888 of 12 August 2008 (Uzasadnienie rzadowego projektu ustawy o zmianie ustawy - Kodeksy rodzinny i opiekuńczy oraz niektórych innych ustaw, druk nr 888 z 12 sierpnia 2008), http://orka.sejm.gov.pl/Druki6ka.nsf/0/68047150EDDA8EB1C12574B8004D19C7/\$file/888.pdf.pl

12 For further information, see: Z. Radwański (ed.), Zielona Księga. Optymalna wersja Kodeksu Cywilnego, Warszawa 2006. 
or are even unsuitable for - as stated in the justification - the "European definition of family relations." 13

Admittedly, the numerous amendments to the applicable Family and Guardianship Code were mentioned in the statement of reasons for the draft of the new Family Code, but - in the opinion of the authors of that statement - "they mostly did not influence the improvement of the situation of the child and the family." This view should also be controverted, though it is difficult because those authors generally did not use any substantive arguments. The level of the effectiveness of normative changes is a derivative of not only the content of the norm, but also the practice of its application. The potential ineffectiveness of a provision does not mean that it is defective from the legal point of view. The problem may lie in the area of the practice of applying that provision. Therefore, each significant change to a specific legal institution, and even to an individual provision which shapes this institution (not to mention the entire Code!) requires research concerning the practice of the application of the law. Only considering both of the mentioned aspects - theory and practice - provides a proper (real) insight into the essence of the analysed issue, which, in turn, conditions the selection of one of two possible decisions, i.e about changing a legal norm or modifying the practice. Not considering the practice of applying the provision results in the fact that the authors risk the allegation which they raise themselves with regard to the earlier amendments, i.e. of the lack of influence of the proposed changes on the improvement of the situation of the child and the family. The issues signalled above are significant especially in reference to the provisions of the family law, which are particularly sensitive to changes due to the subject and nature of these provisions. They require particular caution from the legislator when they are made, especially when they are of such a revolutionary nature, as the authors of the draft declare. ${ }^{14}$ One cannot make law without knowing the effects of its functioning. The new law cannot be "tested" on the living organism of children, and cannot be changed only after "the test" goes wrong. "Testing" should be conducted earlier, in the form of the results of scientific research and discussions with experts, especially psychologists, pedagogues and other assemblies which the draft should be consulted with.

The statement of reasons for the draft, which has been quoted numerous times, also includes fragments which are difficult to controvert rationally. As a form of

13 See: W. Stojanowska, M. Kosek, O rzekomej potrzebie..., p. 156.

14 For further information, see: M. Kosek, O odpowiedzialne i uzasadnione nowelizowanie Kodeksu rodzinnego i opiekuńczego na przykładzie projektu Parlamentarnego Zespołu na Rzecz Praw Dzieci do Obojga Rodziców z 10 marca 2016 roku, [in:] S. Godek, R. Kamińska (eds.), Przyszłość rodziny w UE, Warszawa 2017, p. $75 \mathrm{ff}$. 
a kind of exemplification, one may indicate a view which was expressed in the justification. Under this view, "one of the main mechanisms of failures in the family is the loss of the ability to think rationally and responsibly,"15 as well as a statement according to which "the number of legal acts, including international ones, which contain the term family, is an important argument that discussions on the distinctiveness of the family law are just and still valid."16 Such claims do not show the substantive level of the statement of reasons for the draft in a good light, which may, in turn, raise justified concern as to the quality of the designed normative solutions.

\section{The Standard of the Work on the Draft}

Developing a new draft of a legal act with the status of a code is certainly an ambitious plan. Not only are substantive issues (preparing the individual provisions of the draft) essential in achieving aims of this type, but so are organisational issues, including the clearly specified procedure of the work of the Commission, the principles of passing resolutions, the potential reassumption of votes, and the like. In this regard, the work of the Codification Commission from 1956 may serve as a kind of standard. Quite well preserved archives provide an insight into that work. ${ }^{17} \mathrm{In}$ reference to the work on the draft of the new code, consultations preceding its preparation, as well as consultations taking the form of notes to the final version of the draft, which precede its direction to the Sejm, should not be underestimated. In relation to the former, in the statement of reasons for the discussed draft of the new Family Code, reference is made to deliberations with judges on "the condition of the family law and judiciary." They were conducted in 2012 at the initiative of the Ombudsman for Children. Their results, as the further part of the justification shows, inclined the Ombudsman to appoint the Social Codification Commission whose task was to prepare the draft of the new code. It is a pity that no more detailed information on this topic was included in the statement of reasons, especially what exactly the subject of those consultations was, and how large the number of judges speaking in favour of the potential changes was, and where these changes should go. As for the consultations giving opinions on the draft, there is no information about them. After reading the statement of reasons, there arises a doubt as to whether the consultations took place at all, and there is even a belief that the authors did not need them. In this context, it is justified to conclude that after the draft Code

15 See: Statement of reasons for the draft, p. 101.

16 Ibidem, p. 96.

17 For further information, see: P. Fiedorczyk, Unifikacja i kodyfikacja prawa rodzinnego w Polsce (1945-1964), Białystok 2014, p. $293 \mathrm{ff}$. 
has been prepared by the Commission, it was simply presented at a press conference, published on the website of the Ombudsman for Children and sent - as it has already been mentioned - to specific entities (e.g. the President of the Republic of Poland, the Marshals of the Sejm and the Senate), with the suggestion of undertaking a legislative initiative the purpose of which would be to adopt the draft. This type of practice excludes the possibility of a real and substantive debate on the draft. There is no place or time for that in the course of parliamentary work.

The procedure of adopting the applicable Family and Guardianship Code looked very different. ${ }^{18}$ After adopting the draft in the Codification Commission in September 1959, the text of the draft was published in 3,000 copies. A questionnaire covering the key issues which emerged during the work in the Commission was attached to the text. The aim of the questionnaire was not so much to limit public discussion on the draft as to set its direction. ${ }^{19}$ The scale of the discussion was impressive. Not only did institutions, appointed for this purpose, somewhat by profession, participate in it, but so did associations, representatives of legal sciences (including individual faculties of law), as well as "common" citizens. ${ }^{20}$ The discussion provided a big amount of material for further work on the draft in the Codification Commission in the course of the second reading of the draft. Obviously, not every bill was subject to such wide discussion. The fact of conducting it in relation to the Family and Guardianship Code undoubtedly shows the awareness of the contemporary government - which was, as it is known, a Communist one - as regards the specific nature of the norms of the family law and its impact on social life. It is a pity that in this course of the work on the draft of the new Family Code, one did not opt for a similar social debate. It would allow for the substantive and social verification of the draft's objectives and detailed normative solutions resulting from these objectives. The lack of the aforementioned wide social consultation is even more incomprehensible when one considers numerous declarations included in the statement of reasons for the draft, such as: "the reform proposed in the draft Family Code creates a new system of the family law." ${ }^{21}$ The comparison of how the adoption of the fundamental legal act concerning the family and the child was treated in the time of the communist system with the way of preparing the discussed draft now in free Poland is embarrassing and saddening.

\footnotetext{
18 Ibidem, p. $462 \mathrm{ff}$.

19 Ibidem, p. 465.

20 Ibidem, p. $502 \mathrm{ff}$.

21 See: Statement of reasons for the draft, p. 101.
} 


\section{The Structure of the Draft}

It is not the aim of this paper to analyse the structure of the discussed draft Code in detail. This is because it goes beyond the scope of the article. However, as part of the general description of the draft, it befits one to devote a few words to this question, pointing out certain issues arising against this background.

The draft of the new Family Code contains provisions of the substantive, procedural, and execution law. This move was justified by "the complex attitude towards the topic of the family law," ${ }^{22}$ which - in the opinion of the authors of the justification - is a feature of the draft. In comparison with the applicable Family and Guardianship Code, the systematics of the regulated issues was also changed essentially. The draft consists of seven books, with the first five of them covering substantive law provisions, whereas the last two contain regulations concerning proceedings in family cases (book six) and executive proceedings (book seven). The aforementioned substantive part of the draft, contained in five books, covers general provisions (book one), regulations concerning the family (book two), marriage (book three), maintenance law (book four), and guardianship (book five).

The structure and systematics of the individual issues, which was adopted in the draft, raises fundamental doubts. It is not justified enough, either substantially or practically in comparison with the clear structure of the applicable Code. The systematics adopted in the draft leads to paradoxes, which is exemplified by the regulation of the institution of marriage. The conclusion of marriage was regulated in the second book of the draft, as part of the provisions regulating "the relations creating the family" (title II), whereas the other provisions concerning marriage, including its cessation, were placed in book three, entitled "Marriage".

Numerous doubts are raised by the first book of the draft - "The General Provisions". It covers three titles: preliminary provisions, the principles of the family law, definitions of statutory terms. Doubts are raised especially by title III - definitions of statutory terms. It is extensive. It covers not only new terms, introduced by the project promoter, but also commonly used terms which have had an established meaning in the doctrine for a long time (e.g. guardianship, custody, consanguinity, affinity, party to the proceedings), which do not require a statutory definition. The new terms mentioned above include: "consensual custody", "equivalent custody", "parenting situation", "family relations", and "personal relations". They were phrased for the use of the designed normative solutions, but the advisability of introducing them raises doubts. For instance, pursuant to Article 152 of the draft, "Personal relations and family relations should provide the right parenting situation for the

22 See: ibidem, p. 103. 
child." In turn, shaping the right parenting situation is the parents' duty, realised in the framework of the obligation to raise the child, pursuant to proposed Article 121. It is worth asking, what does result from the quoted provisions "in a new linguistic layout"? It is not difficult to answer that these statements not only do not contribute anything to the matter which is already complex enough, but they also make it more complicated. ${ }^{23}$

It is already here that it befits one to formulate a conclusion which is drawn after reading the draft and its justification: the applicable Family and Guardianship Code is not an anachronistic legal act and it still can and should function as the basic regulator of legal-family relations in Poland. The proposal to replace it with a new code - apart from the substantive evaluation of the draft - is not justified enough either legally or socially. From the considerations so far, one may draw one more conclusion concerning the discussed draft of the Family Code. Despite the perhaps good intentions of the authors, the draft does not meet the basic standards for this kind of legal acts. Sending this draft to the President of the Republic of Poland, the Marshals of the Sejm and the Senate of the Republic of Poland, in order to undertake a legislative initiative - apart from the substantive issues discussed below - should be determined as not only pointless, but even dangerous for the stability of family-legal regulations, which was shaped by the latest amendments to the family law. ${ }^{24}$

\section{Some Detailed Issues}

As it was mentioned in the introduction, the purpose of this paper is not to make a detailed analysis of all key legislative solutions formulated in the discussed draft of the Family Code. In any case, in practice, it would be impossible to do it in one article due to the number and scope of the changes. Therefore, focus was given the provisions regulating two legal institutions which are essential from the point of view of the child's welfare, that is, parental authority and divorce both of which were regulated in significantly different ways (which raise fundamental doubts) in the discussed draft in comparison with the applicable Family and Guardianship Code. The selection of the indicated institutions was dictated not only by the scope of the changes proposed in it, but most of all by their significance from the point of view of protecting the welfare of the child.

\footnotetext{
23 For further information, see: W. Stojanowska, M. Kosek, O rzekomej potrzebie..., p. 158 ff.

24 Ibidem, p. 159.
} 


\section{The Institution of Parental Authority}

An important change included in the draft of the discussed Family Code, according to the justification, "is replacing the pejorative term 'parental authority', which is used in the applicable Family and Guardianship Code, with parental responsibility." 25 The term of "parental responsibility", as assessed by the authors of the statement of reasons, "removes a form of power over the child from the parents" and "indicates an emphasis on the subjectivity of the child in the family." 26

The idea of introducing parental responsibility into the Polish family law has its supporters. One of them is P. Jaros. In his monograph devoted to this issue, ${ }^{27}$ he associates the responsibility of the parents with the child's right to both parents and derives it from the Convention on the Rights of the Child. It seems that the substantive draft of the new Family Code was inspired by that author's views, which is, by the way, mentioned by him in the aforementioned monograph. ${ }^{28}$ For this reason, it befits one to refer to arguments formulated in the doctrine, ${ }^{29}$ which settle the rejection of that concept.

It is a fact that the Convention on the Rights of the Child uses the term of responsibility, but - which is important - in its classical, civil law understanding. It is indicated by the statement in which the term appears most frequently in the Convention, namely "having responsibility". It occurs i.a. in Article 18 of the Convention, imposing the obligation to recognise the principle, according to which both parents "have common responsibilities for the upbringing and development of the child." There is no doubt as to the fact that the parents' responsibility understood in this way cannot be identified with the concept of parental responsibility (as a replacement for the term "parental authority"). It is not the purpose of the Convention to force "the only right" concept of parental responsibility on states-parties, which constitutes some destination point for the evolution of the provisions of the national law in the discussed matter - as P. Jaros puts it - but to formulate the child's fundamental rights and legal instruments used to protect those rights, which should be respected by the states-parties, regardless of the institutional model of

25 See: Statement of reasons for the draft, p. 120.

26 Ibidem.

27 P. Jaros, Prawo dziecka do rodziców (odpowiedzialności rodzicielskiej) w kontekście polskich zobowiązań międzynarodowych, Warszawa 2015.

28 Ibidem, p. 19.

29 See: W. Stojanowska, Prawo dziecka do wychowywania się w środowisku rodzinnym przewidziane w Konwencji o prawach dziecka (artykut recenzyjny), "Państwo i Prawo" 2019, 1, p. 117 ff. 
the mutual relations between the parent and the child. ${ }^{30}$ The fact of using the term of responsibility in the Convention on the Rights of the Child thus cannot itself constitute the basis for criticising the institution of parental authority.

In this context, one should particularly emphasise the fact that the term "parental responsibility" was introduced into the international law not as the result of the provisions of the Convention on the Rights of the Child, but as part of the so-called standards of the Council of Europe (this is particularly about the Council of Europe's Recommendation No. R (84) 4 of 28 February 1984 on parental responsibilities), ${ }^{31}$ and it is used in the system of the European Union, is not insignificant. ${ }^{32}$ Therefore, one may not reasonably claim that from the point of view of Polish international obligations, especially including the provisions of the Convention on the Rights of the Child, there is an obligation to absolutely adapt the Polish law to provisions included in recommendations or resolutions of the Council of Europe, also in terms of vocabulary presented there, which is expressed in the postulate of incorporating the term "parental responsibility" in the local law. Such a postulate is not justified, even more so since - when it comes to the substance - the Polish law meets all the standards resulting from those legal acts. ${ }^{33}$

The idea of replacing the term of parental authority with different wording is not new. It was the subject of considerations in the doctrine, ${ }^{34}$ as well as discussions in the Codification Commission for Civil Law as part of the work on the aforementioned amendment of 6 November 2008 to the Family and Guardianship Code. In the end, the Commission spoke negatively on this topic. The arguments which formed the basis for the decision of the Codification Commission are worth mentioning here. ${ }^{35}$ Firstly, the Commission noted that the parents "should have 'powerful' competences regarding the person and property of the child," who due to the state of his or her state of (psychological, intellectual, physical) development and lack of life experience is not able to make his or her own decisions which are adequate (right) for his or her welfare. The fact that the parents have some "powerful"

$30 \quad$ Ibidem, p. 120.

31 See: Rekomendacja Rady Europy nr 84(4) w sprawie odpowiedzialności rodzicielskiej, przyjęta przez Komitet Ministrów Rady Europy 28 lutego 1984 r., [in:] M. Safjan (ed.), Standardy prawne Rady Europy, Vol. 1, Prawo rodzinne, Warszawa 1994, p. 201 ff.

32 For further information, see: C. Mik, Międzynarodowe prawo rodzinne Unii Europejskiej na tle ewolucji wspótpracy sądowej w sprawach cywilnych, [in:] L. Ogiegła, W. Popiołek, M. Szpunar (eds.), Rozprawy prawnicze. Księga pamiątkowa Profesora Maksymiliana Pazdana, Katowice 2005, pp. 209-224.

33 For further information, see: W. Stojanowska, Rekomendacja $\mathrm{Nr} R(84) 4$ w sprawie odpowiedzialności rodzicielskiej a stan prawny obowiazujący w Polsce, [in:] M. Safjan (red.), op. cit., p. $217 \mathrm{ff}$.

34 Critically on this topic, see: ibidem, p. $218 \mathrm{ff}$.

35 For further information, see: Z. Radwański (ed.), op. cit., p. 157. 
competences obviously does not exclude considering the child's opinion, and even that child's co-deciding when comes to matters concerning the child. From this point of view, in the Commission's opinion, the sole replacement of the term "authority" with parental "responsibility" or "custody" does very little, and it is doubtful for the change to have any essential educational ring to it. ${ }^{36}$ Furthermore, the Commission noted that the "masterfulness" of the parents' competences concerns not only the child, but also relates to third parties, which occurs during representing of the child before those entities and settling the child's matters. To sum up, the term "parental authority" is - in the Commission's opinion - "adequate wording for the parents' role in the area of upbringing the child in relation to other entities," considering that, according to Article 48 of the Constitution of the Republic of Poland, the parents are "the first" educators. This term, in the Commission's view, "better captures" the autonomy which the parents are entitled to as regards exercising their rights and duties. ${ }^{37}$

Despite the clear opinion of the Codification Commission for Civil Law, discussed above, and convincing arguments, the doctrine still forms postulates of rethinking the terminology used by the legislator in reference to the discussed institution. ${ }^{38}$ These postulates also come from environments which deal with broadly understood help for families. These environments indicate some parents' superficial and incorrect understanding of the essence of parental authority. This understanding involves exposing the parent's child-related rights at the cost of that parent's duties, which frequently leads to abuse, and in extreme cases - to violence against the child. The change in terminology alone will certainly not solve the problem indicated above, but perhaps this could be a step in the right direction. In the opinion of the authors of the present paper, if the Polish legislator decided to change the name of the institution of parental authority, replacing it with the term "parental custody" would have to be considered first. The substantive change was already postulated during the work of the Codification Commission from 1956. The postulate of replacing the term "parental authority" with the term "parental custody" was submitted by J. Gwiazdomorski during the work on the Family and Guardianship Code. ${ }^{39}$ Then the postulate did not win the support of the rest of the Commission members, and was rejected but it is still present in the doctrine,$^{40}$ and it should be considered. It would definitely be wrong - in the

\footnotetext{
36 Ibidem.

37 Ibidem, pp. 157-158.

38 See e.g.: J. Strzebinczyk, Prawo rodzinne, 4th edition, Warszawa 2013, p. 247.

39 See: P. Fiedorczyk, op. cit., p. 411.

40 See: J. Strzebinczyk, op. cit., pp. 247-248.
} 
opinion of the authors of this paper - to introduce the expression "parental responsibility" because, among other things, it "collides" with the civil law meaning of the term "responsibility". One should expect that the criticism of the expression "parental authority" will still appear in the doctrine. If the term "authority" is so "paralysing", perhaps it should be given up and replaced by the word "custody", by adjusting elements of the definition of "parental authority" to its change into "parental custody". The proposed change will balance the area of the parent's duties and rights in relation to the child.

\section{Divorce Premises in the Draft of the New Family Code}

The issue of divorce with regard to substantive provisions was regulated in the discussed draft in Articles 219 to 226. Article 219 of the draft concerns the divorce premises. This provision retains a positive premise for divorce that is the irretrievable breakdown of marriage, and three so-called negative premises which make the dissolution of marriage impossible, despite the existence of the positive premise, and in comparison with the applicable state of law in the discussed matter (Article 56 of the FGC), certain important, as it seems, changes were applied to each of those premises. The premise of the welfare of the underage children whom the spouses have in common was replaced by the premise of "the welfare of the child raised together," and the premise of a contradiction of divorce with the principles of social co-existence was replaced by the premise of a contradiction of divorce with the so-called principles of family law. The project promoter also abandons the term of guilt for the failure of the marriage, replacing it with the expression "responsibility for the failure of the marriage". In consequence, according to the indicated Article $219 \S 3$, divorce would be inadmissible if it was demanded by the spouse solely responsible for the failure of the marriage, unless the other spouse agrees to the divorce or that spouse's refusal is contradictory to the so-called principles of family law in given circumstances.

Justifying the advisability of the changes described above raises fundamental doubts. The argument that the applicable state of law in the discussed matter provides protection only for the underage children of the spouses in the case of divorce, and it deprives the child, whom the spouses raise together and "whose parent is one of the spouses," is not convincing. ${ }^{41}$ On a side note, it befits one to notice that the discussed negative premise for divorce was limited in the statement of reasons for the draft by indicating that this is about a child whose parent is one of the spouses. The way in which Article 219 of the draft was edited indicates

41 Statement of reasons for the draft, p. 110. 
a wider subjective scope of this premise. The scope covers each child that is raised by the spouses together. Apart from the indicated discrepancy between the content of the provision and its justification, it should be emphasised that in the light of the applicable Article 46 of the FGC, the protection of the child raised by the spouses together is possible. The basis for this protection is the general clause of the principles of social co-existence, as the negative premise for divorce. Perhaps the problem lies in the case-law practice, and not in the content of the provision.

Even greater doubts and interpretational difficulties are caused by replacing the general clause of the principles of social co-existence with the so-called principles of family law in the discussed Article 219 of the draft. The aforementioned general clause, in spite of its communist origin - in any case, such an origin could be attributed to many provisions - matched well with the practice of divorce courts and it has an established interpretation. Replacing it with another clause - and a completely new one, created $a d$ hoc - would only cause unnecessary confusion in the case-law practice. In this context, an essential difficulty would also be cataloguing the above-mentioned principles of family law in the draft. This raises a question about their compatibility with the issue regulated by the provisions of the divorce law. In title II of the first book of the draft (Article 7-20 of the draft), 14 principles were enumerated, i.a. the principle of the child's subjectivity, the principle of the child's welfare, the principle of listening to the child, the principle of protecting the family, as well as the principle of the non-discrimination of the child and family, and the principle of solving family conflicts and disputes by mediation. In this context, a question is raised which of the principles of the family law enumerated in the draft could constitute the basis for "lifting" the refusal of the innocent spouse (in the draft - the one who is not solely responsible) and, in consequence, a divorce ruling. The principle of the child's welfare may come into play, but it constitutes a separate divorce premise. Alternatively, it could be the principle of protecting the family or the principle of upbringing the child in the family environment, but these principles, in turn, counteract the divorce ruling in essence.

Equally fundamental doubts and interpretational difficulties are caused by the third designed change, but it does not concern only the premises for divorce, but also the effects of divorce, including the maintenance obligation between the divorced spouses. This is about the replacement of the expression "guilt for the failure of the marriage" with the expression "responsibility for the failure of the marriage". Assuming an attitude towards this proposal, one should note first that in this case, the statement of reasons for the draft lacks any information on the grounds or purpose of the discussed change. If the authors of the draft meant abandoning the category of fault in the divorce law, it should be stated that the operation made is beside the point. Replacing the term "guilt" with the term "responsibility" does not make the 
question of guilt not taken into consideration by the divorce court. After all, the category of responsibility has the form of responsibility for guilt in the family law. If the divorce court was obligated to determine which of the spouses is responsible for the failure of the marriage, it would be able to do it only by verifying the reasons for the divorce. The reasons are generally situated on the grounds of exercising one's marital rights and duties. The proposed change thus contributes little in comparison with the applicable practice if there is no situation of withdrawing from accounting guilt for divorce upon the spouses' mutual request (Article 57 of the FGC).

A similar conclusion - about the pointlessness of the discussed change - may be drawn against the background of Article 225 of the draft regulating the maintenance obligation between the divorced spouses. In comparison with the applicable state of law (Article 60 of the FGC), the designed change also involves only the replacement of the term of guilt with the term of responsibility, with analogous consequences as in the case of Article 219 of the draft.

In the context of the designed, above-discussed changes, it is worth referring to the opinion of the Constitutional Tribunal ${ }^{42}$ regarding the meaning of the category of guilt in the Polish family law, based on the assessment of the compatibility of the above-mentioned Article 60 of the FGC with the Constitution of the Republic of Poland (i.a. its Article 31 section 3). ${ }^{43}$

With reference to the contested provision of Article $60 \S 2$ of the FGC, the Tribunal emphasised that "this provision constitutes an expression of the legislator's preferences in socially important matters because they concern marriage - namely, the assumption that the attitude of the innocent spouse, who fulfilled their marital duties correctly, deserves a kind of acknowledgement and approval, expressed in the need for protecting their financial situation against significant worsening due to the divorce, whereas the attitude of the guilty spouse should be evaluated negatively, and their financial interests deserve relatively smaller protection." This seems - in the opinion of the Tribunal - even more justified (just) that the negative attitude of the spouse who is solely guilty - solely responsible for the failure of the marriage, and in consequence, for the divorce - leads to a change not only in their own interests, but also in the interests of the other spouse "who frequently not only did not contribute to the failure of the marriage, but even tried to counteract that failure." The so expressed ratio legis of the Article $60 \S 2$ of the FGC should be evaluated - in the opinion of the Tribunal - as "corresponding to the constitutional principle of the state protection and care of the marriage and the family (see Article

\footnotetext{
42 See: Order of the CT of 25 October 2012, SK 27/12, OTK-A 2012, No. 9, item 109.

43 For further information, see: W. Stojanowska, [in:] T. Smyczyński (ed.), System Prawa Prywatnego, Vol. 11, Prawo rodzinne i opiekuńcze, 2nd edition, Warszawa 2014, p. 839 ff.
} 
18 of the Constitution) and taking these factors into account in the state social and economic policy (see Article 71 of the Constitution)." ${ }^{\prime 44}$ It also deserves approval from the point of view of social justice (Article 2 of the Constitution), as an expression of the principle nemo turpitudinem suam allegans audiatur.

The above-mentioned decisions of the Tribunal lead to a basic conclusion which should be fully approved: "considering such a strong attachment of the premise of guilt from Article $60 \S 2$ of the FGC to the axiology of the Basic Law and the family law, its application as a criterion of the extended maintenance obligation seems justified." 45

What is particularly important in the assessment of the opinion of the Constitutional Tribunal is the attachment of the premise of guilt from Article $60 \S 2$ of the FGC in the constitutional axiology and the family law. This stance may be regarded as a peculiar answer to proposals, which are sometimes submitted in the doctrine, for a radical remodelling of the maintenance obligation between former spouses. An example of this type of proposal may be e.g. the view, according to which the justification of the maintenance obligation between the former spouses is "the need for making up for the spouse's loss as the result of staying in the marriage, especially as the result of the division of roles," whereas "guilt in causing the failure of the marriage has nothing to do with the economic consequences of staying in the marriage." ${ }^{\prime 6}$ Proposals of this type mean "freeing" the maintenance obligation from the premise of guilt, which is not so much their result as their basic objective. This is because in the background of these views, there is a tendency to completely abandon the term of guilt in legal-family relations, especially regarding the marriage and divorce law. This means decomposing the current model of the divorce law and replacing the current axiology, which the Constitutional Tribunal referred to in the above-quoted order, with a new one. Its paradigm is making the legal-family relationships independent from the category of guilt. Let us hope that the Polish legislator will not go this way. ${ }^{47}$

\footnotetext{
44 See Order of the CT of 25 October 2012, SK 27/12, OTK-A 2012, No. 9, item 109, part III, point 2.3.

45 Ibidem.

46 See: B. Swaczyna, Obowiązek alimentacyjny między bytymi matżonkami de lege ferenda, [in:] P. Machnikowski, J. Gołaczyński (eds.), Wspótczesne problemy prawa prywatnego. Księga Pamiątkowa ku czci Profesora Edwarda Gniewka, Warszawa 2010, p. 596.

47 For further information, see: W. Stojanowska, [in:], T. Smyczyński (ed.), op. cit., p. 841 ff.
} 


\section{Conclusions}

Preparing a new act with the status of a code, that is, an act which organises the entirety of a given branch of law, is a task that requires the fulfilment of many premises, both formal-legal ones and substantive (objective) ones at every stage of the work - the preliminary (organisational) stage, the substantive stage (work in the Commission), and the consultation stage (social consultations concerning the first version of the draft. This concerns every code, especially in a field as sensitive, also to changes, as the family law, with the principle of protecting the child's welfare which is exposed so much.

The discussed draft of the Family Code raises fundamental doubts in each of the enumerated stages of work. Not much is known about the Commission itself that is developing the draft of the discussed Family Code, particularly with regard to its work plan or internal decisions concerning the procedure of the work. It is not even known whether there was any draft serving as a starting point for the Commission's work, as was in the case of working on the draft of the applicable Family and Guardianship Code. ${ }^{48}$

A good practice - as mentioned above - used by the Codification Commission which prepared the applicable Family and Guardianship Code, was a wide discussion forum (conferences, readings, and the like) which served the exchange of opinions on the one hand, especially when it came to the most debatable issues. On the other hand, it provided information on the progress of the codification work. The aforementioned discussions were initiated numerous times by the members of the Codification Commission themselves, who participated in its work. In this context, the discussed draft of the Family Code does not correspond to the standards established by the work of the above-mentioned Codification Commission.

The evaluation of the advisability and legitimacy of the draft, formulated in this paper, as well as the analysis of some of its detailed normative solutions confirm the above-posed opinion: the draft does not meet the basic standards for this kind of legal acts. Sending the draft to the President of the Republic of Poland, and to the Marshals of the Sejm and the Senate of the Republic of Poland, in order to undertake a legislative initiative, seems not only premature and pointless, but even dangerous for the stability of the legal-family regulations, which was shaped by the latest amendments to the family law. This evaluation is not changed by the positive assessment of some of the proposed solutions, included in the draft of the discussed Code, especially in regard to restoring conciliation meetings and strengthening the institution of mediation, which can and should be introduced by way

48 For further information, see: P. Fiedorczyk, op. cit., p. 285 ff. 
of amending the applicable Code, without the necessity of preparing a completely new normative act.

The analysis of the work on the discussed Family Code leads to a more general conclusion regarding the process of introducing changes to the rules of law. Such a conclusion, ideally corresponding to the current reality, has already been formulated in the doctrine before. The essence of the issue was accurately presented by J. Winiarz in his work devoted to the evolution and perspectives of the Polish family law of a bygone era: "Every, even the slightest change of the state of law causes serious repercussions. It shakes the structure of established judicature, becomes a source of doubts. The excessive dynamism of legislative activity is particularly dangerous, and, as its result - the fluctuation of the state of law. In reference to the relations of the family law, the legal rationing of which covers in essence 'the external side' (and if it enters the internal area, it has to do it with particular caution and moderation), in regard to which the process of assimilating norms and thereby of the educational influence of the law, occurs slowly, the risk of the negative effects of the revisions, which were not considered carefully enough, of the applicable provisions increases. Therefore, all the changes should be introduced when fully convincing arguments support the necessity of these changes." 49

The above-cited opinion of J. Winiarz has lost none of its relevance. It seems even more valid today than in the period in which it was formulated.

The present paper is a presentation delivered in Gdańsk at a Polish scientific conference entitled "Akademicki Projekt Kodeksu Cywilnego" (The Academic Draft of the Civil Code), organised by the Faculty of Law and Administration of the University of Gdańsk on 23-24 May 2019.

49 See: J. Winiarz, Socjalistyczne prawo rodzinne PRL. Ewolucja - stan prawny - perspektywy, "Studia Prawnicze" 1974, 4(42), p. 57 ff. 